\title{
MECHANISMS OF ORGANOPHOSPHATE TOXICITY AND DETOXICATION WITH EMPHASIS ON STUDIES IN CROATIA*
}

\author{
Elsa REINER ${ }^{1}$, Zoran RADIĆ ${ }^{2}$, and Vera SIMEON-RUDOLF ${ }^{1}$ \\ Institute for Medical Research and Occupational Health, Zagreb, Croatia ${ }^{1}$, Skaggs School of \\ Pharmacy and Pharmaceutical Sciences, University of California at San Diego, La Jolla, CA, \\ USA ${ }^{2}$
}

Received in July 2007

Accepted in August 2007

\begin{abstract}
This review comprises studies on the mechanisms of toxicity and detoxication of organophosphorus (OP) compounds done in Croatia in different research areas. One area is the synthesis of antidotes against OP poisoning and their in vivo testing in experimental animals. In vitro studies included in this review focus on the mechanisms of reversible inhibition of acetylcholinesterase $(\mathrm{AChE})$ and butyrylcholinesterase (BChE), protection of cholinesterases from inhibition by OPs, and reactivation of phosphylated cholinesterases. The third area comprises distribution profiles of $\mathrm{BChE}$ and paraoxonase (PON) phenotypes in selected population groups and the detection of OPs and metabolites in humans. Finally, methods are described for the detection of OP compounds in human blood and other media by means of cholinesterase inhibition.
\end{abstract}

KEY WORDS: acetylcholinesterase, antidotes against organophosphates, butyrylcholinesterase, detection of organophosphates, interaction of organophosphates with esterases, paraoxonase

Organophosphates (OP) compounds are toxic supstances that are primarily used as pesticides. Some OPs are drugs, and several most toxic OPs are warfare nerve agents. Cholinesterases (AChE and $\mathrm{BChE}$ ) and phosphoric triester hydrolases (PON and DFPase) are involved in the toxicity and/or detoxication of organophosphates. AChE (acetylcholinesterase; EC 3.1.1.7) and BChE (butyrylcholinesterase; EC 3.1.1.8) are inhibited by OPs, while PON (paraoxonase; EC 3.1.8.1) and DFPase (EC 3.1.8.2) hydrolyse organophosphates. The molecular structure of these enzymes and their mechanisms of interaction with OPs have generally been resolved and understood. Present studies are mainly focused on enzyme structure, role of individual residues in the enzyme interaction with OPs, search for effective antidotes and decontaminating agents for OPs, and on developing methods to identify OPs and their metabolites in humans and the environment.

This paper summarizes studies on the toxicity and detoxication of organophosphorus compounds that have been conducted in Croatia. The paper was presented as an introductory lecture to the symposium on OP compounds held in Croatia as part of the EUROTOX 2006 Congress (1).

\section{SYNTHESIS OF ANTIDOTES AND THEIR IN VIVO TESTING IN EXPERIMENTAL ANIMALS}

Organophosphorus compounds are toxic primarily due to the inhibition, i.e. phosphylation, of the active

\footnotetext{
* Partly presented at the EUROTOX 2006/6 CTDC Congress - Symposium on Molecular Mechanisms of Organophosphates, Cavtat, Croatia, 20-24 September 2006.
} 
<smiles>[X][N+]([O-])=NCc1ccc[n+](C)c1</smiles>

$\mathrm{HON}=\mathrm{HC}$<smiles>[Y]C=NCc1cc[n+](CCC[n+]2ccccc2)cc1</smiles>
$2 X^{-}$

$\mathrm{HON}=\mathrm{HC}$<smiles>[Y]C=NC[n+]1ccc(C=N[OH2+])cc1</smiles>
$2 X^{-}$
TMB-4 (Trimedoxime)

PAM-2 (Pralidoxime)

LuH-6 (Toxogonin, Obidoxime)

$\mathrm{H}_{2} \mathrm{NOC}$<smiles>[Y20]O/N=C\c1ccc[n+](COC[n+]2ccc(C)cc2)c1</smiles>

$\mathrm{HI}-6$

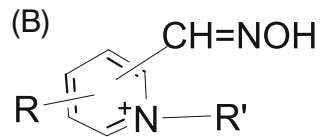

Py<smiles>[R]n1cc[n+]([R])c1O</smiles>

Im<smiles></smiles>

Q

Figure 1 (A) Structure of conventional antidotes $\left(X^{-}\right.$is an anion) used in the treatment of OP poisoning and (B) general structure of quaternary pyridinium (Py), imidazolium (Im) and quinuclidinium (Q) derivatives described in reference (7)

site serine in AChE. The standard treatment of OP poisoning therefore includes oximes as reactivators of the inhibited AChE and atropine as an antimuscarinic drug.

Of many prepared and tested antidotes, only several oximes have found clinical application so far, and these are PAM-2, TMB-4, HI-6 and Toxogonin (cf. 2). All four compounds are quaternary pyridinium derivatives (Figure 1A). No oxime antidote is effective against a wide range of $\mathrm{OP}$ compounds, and the search for more effective antidotes continues (3-6). Treatment of OP poisoning still poses a problem. This applies in

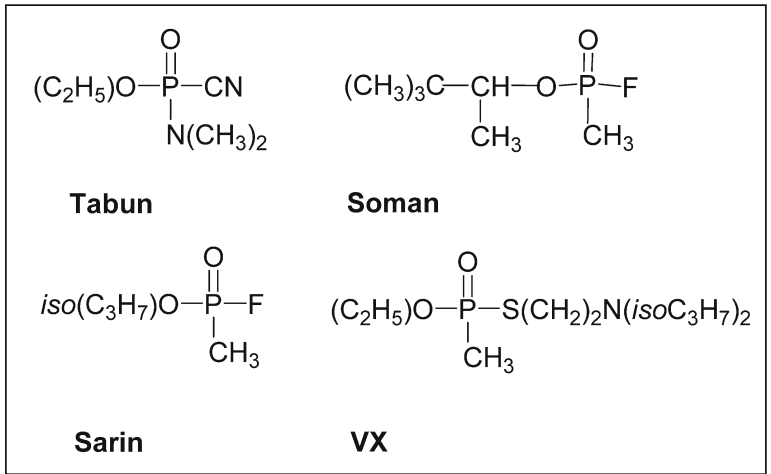

Figure 2 Organophosphorus warfare nerve agents particular to OP warfare agents (Figure 2) and among these in particular to Tabun and Soman.

About 150 compounds have been synthesized in Croatia over about three decades (7). These compounds are mono- or bis-quaternary pyridinium (Py), imidazolium ( $\mathrm{Im})$ and quinuclidinium $(\mathrm{Q})$ derivatives, and conjugates containing two different moieties (PyIm, PyQ, ImQ) with one or two oxime groups in the molecule. The general structure of these compounds is shown in Figure 1B. About one third of the compounds were tested against Tabun and Soman by applying a standardised testing protocol (cf.8).

Tabun or Soman were given subcutaneously to mice or rats. The antidotes were applied intraperitoneally (together with atropine) immediately after OP. The antidotal effect was expressed as the therapeutic factor (TF), which is the ratio between $\mathrm{LD}_{50}$ of the OP compound (after $24 \mathrm{hr}$ observation) in the presence and in the absence of antidotes:

$$
\mathrm{TF}=\mathrm{LD}_{50}\left(\mathrm{OP} \text { plus antidote) } / \mathrm{LD}_{50}\right. \text { (only OP) }
$$

When different antidotes are compared against a given OP, they must be applied at equitoxic doses. This was not strictly observed in the above protocol, 
although the dose of the majority of oxime antidotes corresponded to $1 / 4$ of its $\mathrm{LD}_{50}$.

Of 32 compounds that had TF above 2.0, the highest were obtained with the two compounds shown in Table 1. One is a heterocyclic quaternary quinuclidinium-imidazolium oxime and the other a bis-quaternary imidazolium di-oxime. In the group of 32 antidotes, no correlation has been established between the compound structure and antidotal effect, and no correlation between the effects against Tabun us. Soman.

The applied testing protocol probably includes both the prophylactic and therapeutic effects because the antidotes were given immediately after the OPs. By modifying the protocol these two effects could probably be studied separately.

Protocols applied at present also include pretreatment of animals with the antidote. This proved very beneficial against Tabun, when a pyridinium oxime was given both as pre-treatment drug ( $15 \mathrm{~min}$ before Tabun) and treatment drug (given with atropine, 1 min after Tabun) (9).

The current search for better antidotes continues by preparing new pyridinium oxime derivatives and by preparing glucoconjugates of heterocyclic quinuclidinium, imidazolium and pyridinium oximes $(10,11)$. The general structure of the glucoconjugates is shown in Figure 3A. Tenocyclidine (TCP) and its adamantyl derivatives are studied as adjuvant antidotes to the oximes $(12,13,14)$. Pretreatment with TCP or its adamantyl-morpholine derivative TAMORF (Figure 3B) proved very effective against Soman when given to mice 15 min before Soman, followed by HI-6 (plus atropine) given $1 \mathrm{~min}$ after Soman. The TF value for both compounds was 7.1. When only atropine plus TCP or TAMORF were given 15 min before Soman,

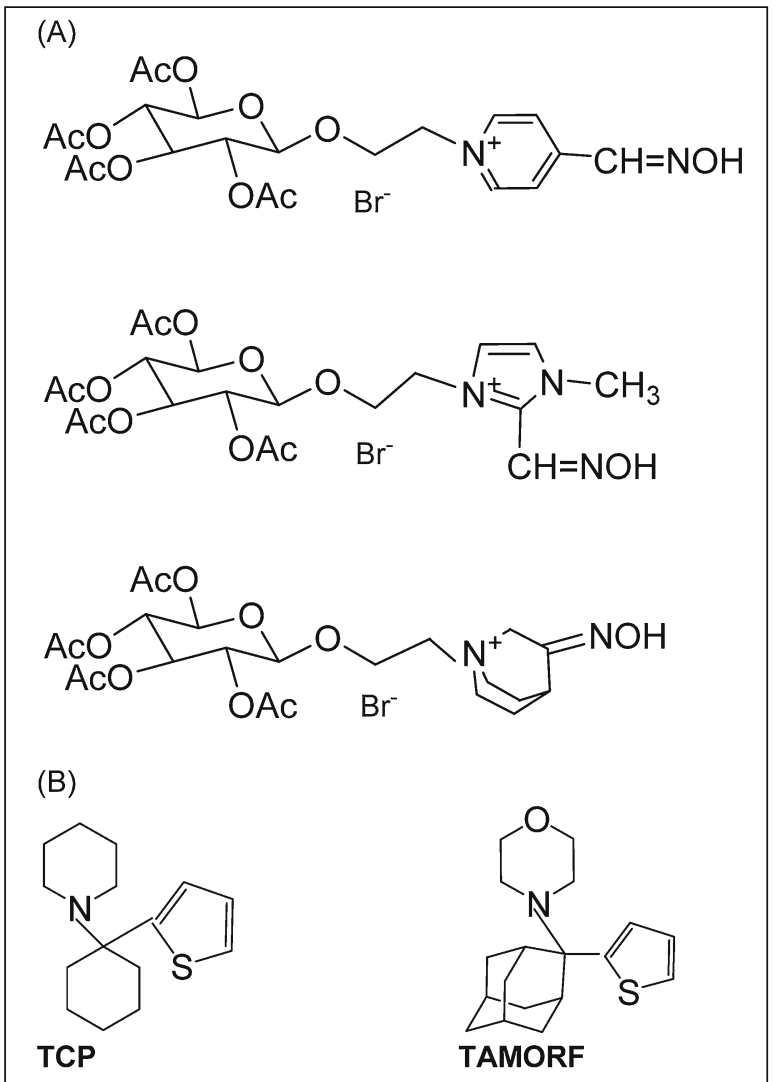

Figure 3 Structure of (A) pyridinium, imidazolium and quinuclidinium glucoconjugates (11) and of (B) tenocyclydine (TCP) and its adamantyl-morpholine derivative (TAMORF)(12)

Table 1 Structure of the oxime antidotes, and TF values against Tabun and Soman tested on mice $\left(^{*}\right)$ and rats(**) (8)

Structure

The testing protocol and the therapeutic factor (TF) are explained in the text. 
or only HI-6 (plus atropine) 1 min after Soman, TF values were 1.7 or 2.8 or 3.7 , respectively.

The most effective compounds described above seem promising candidates that might broaden the present choice of antidotes available for the treatment of OP poisoning.

\section{IN VITRO INTERACTIONS OF ANTIDOTES WITH CHOLINESTERASES}

Oxime antidotes bind to cholinesterases causing reversible inhibition of $\mathrm{AChE}$ and $\mathrm{BChE}$. By interacting reversibly with cholinesterases, they protect the enzyme against phosphylation by OP compounds. Oximes are reactivators of the phosphylated cholinesterases which is their primary property as therapeutic agents. These three reactions are shown in Figure 4.

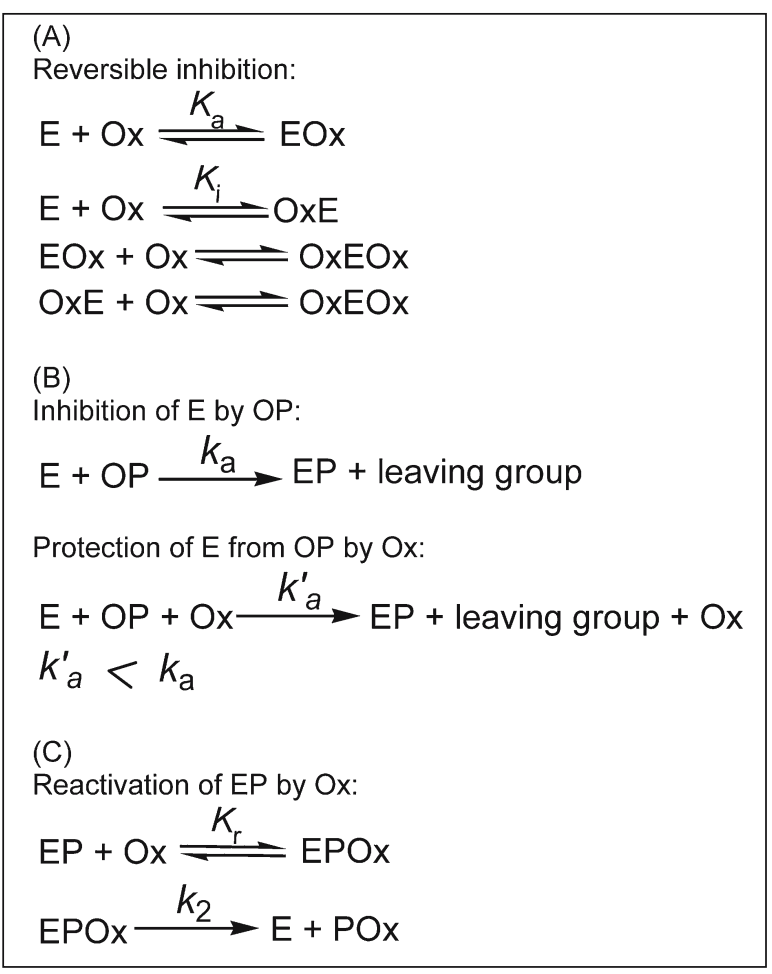

Figure 4 Interactions of oxime antidotes $(O x)$ with cholinesterases: $E=$ active enzyme, $O P=$ organophosphorus compounds, $E P=$ phosphylated enzyme, $P O x=$ phosphylated oxime

$\mathrm{AChE}$ and BChE have two binding sites for substrates and reversible ligands: the catalytic site and the peripheral allosteric site. Binding of a ligand to the catalytic site inhibits the enzyme. The peripheral site is catalytically inactive. However, binding of a ligand to that site affects catalysis. Binding of a substrate to that site causes substrate inhibition or substrate activation. Kinetic models have been postulated and tested for both binding of reversible ligands to the enzyme and protection of cholinesterases from phosphylation (15-21).

Pyridinium, imidazolium and quinuclidinium compounds, both with and without oxime groups in the molecule, are reversible inhibitors of cholinesterases. A detailed study on reversible inhibition should include evaluation of the enzyme-inhibitor dissociation constants to both enzyme sites. Such studies have been conducted only with some conventional antidotes and with a small number of other antidotes. These studies have shown that the majority of compounds bind to both sites in AChE, and that binding is competitive with the substrate. Values of the dissociation constants $K_{\mathrm{a}}$ and $K_{\mathrm{i}}$ (cf. Figure 4A) for binding of the antidotes to the catalytic (EOx) and allosteric $(\mathrm{OxE})$ site of the enzyme are usually in the millimolar range. Almost without exception, the affinity for the allosteric site is smaller than for the catalytic site $\left(K_{\mathrm{a}}<K_{\mathrm{i}}\right)$, as has also been shown for some conventional oximes (22, cf. 7).

Protection of the enzyme from OPs depends on the $K_{\mathrm{a}}$ and $K_{\mathrm{i}}$ constants of the protector, and on protector concentration. Protection of an enzyme from being phosphylated is usually expressed in terms of protective index $(\mathrm{PI})$ :

$$
\mathrm{PI}=k_{\mathrm{a}} / k_{\mathrm{a}}{ }^{\prime}
$$

where $k_{\mathrm{a}}$ and $k_{\mathrm{a}}{ }^{\prime}$ are the second-order rate constants of phosphylation in the absence and in the presence of a given concentration of the protector (cf. Figure 4B). When different protectors are compared against a given $\mathrm{OP}$, the protectors must be studied at equi-inhibitory concentrations.

Compounds that bind to both catalytic and allosteric enzyme sites (OxEOx; Figure 4A) are better in vitro protectors than those that bind to one site only (cf. 16). This property of the antidotes has so far not been considered in in vivo studies.

The ability to reactivate the phosphylated $\mathrm{AChE}$ is the crucial property of an antidote against $\mathrm{OP}$ toxicity. This reaction is defined by the second-order rate constant of reactivation $\left(k_{\mathrm{r}}\right)$ :

$$
k_{\mathrm{r}}=k_{2} / K_{\mathrm{r}}
$$

Effective reactivators should have a high affinity for phosphylated $\mathrm{AChE}$ (i.e. low $K_{\mathrm{r}}$ value) and a high rate constant $k_{2}$ (cf. Figure 4C). Only a few oximes prepared in Croatia have fully been evaluated as reactivators, and no correlation showed up between 
their reactivating and antidotal properties (cf. 7). Reactivating properties of new antidotes prepared outside Croatia are also being studied on $\mathrm{AChE}$ and BChE inhibited by Tabun and other OPs $(23,24)$.

Phosphylated cholinesterases that undergo "ageing" (i.e. dealkylation) do not react with oximes (cf. 21). This is the main reason why oxime therapy is not effective after "ageing" had occurred, which is particularly pronounced in Soman intoxication.

Phosphylated oximes formed during the reactivation process (POx, Figure $4 \mathrm{C}$ ) are very potent cholinesterase inhibitors (cf. 21). Many phosphylated oximes are unstable compounds. However, if a phosphylated oxime is stable, it will re-inhibit the reactivated $\mathrm{AChE}$ in situ. In in vitro studies, this will show-up as incomplete reactivation. So far, only a few oximes have been systematically screened for that reaction, but these do not include the new compounds listed in reference (7). Failure to obtain in vivo reactivation has not been considered as possibly due to re-inhibition of the reactivated AChE.

\section{DISTRIBUTION PROFILES OF BUTYRYLCHOLINESTERASE AND PARAOXONASE ACTIVITIES IN SELECTED POPULATION GROUPS}

Butyrylcholinesterase and paraoxonase are scavengers of OP compounds, and their activities and specificities in a given species are important factors for the toxicity of OPs.

$\mathrm{BChE}$, like other serine esterases, reacts with OPs on a 1:1 molar basis, forming phosphylated esterases. These are no longer capable to react with OPs. However, in the presence of an efficient oxime that reactivates the phosphylated enzyme, $\mathrm{BChE}$ becomes a catalytic scavenger. PON itself is a catalytic scavenger, because OPs are hydrolysed by PONs, and a hydrolysed OP is no longer toxic.

Both BChE and PON have different variants, and these have different activities and specificities for their substrates and inhibitors.

The distribution of human serum BChE phenotypes is shown in Table 2 (cf. 25). Results were obtained from about 1500 healthy male and female adults from Croatia, mainly from Zagreb. Phenotyping was based on activities measured with benzoylcholine, butyrythiocholine and/or propionylthiocholine, and on inhibition with dibucaine, sodium fluoride, urea and the dimethylcarbamate Ro-02-0683. No silent SS phenotype, having no BChE activity, was found in that population, save for a small number of heterozygote phenotypes US and AS. The atypical A variant also had a low frequency. It slowly hydrolyses shortacting muscle relaxants such as suxamethonium, causing prolonged apnoea in patients receiving this muscle relaxant. Several laboratories in Croatia are participating in international and national interlaboratory quality control proficiency studies for

Table 2 Frequency of human serum butyrylcholinesterase (BChE) and paraoxonase (PON) phenotypes in population groups from Croatia (25, 28-30)

\begin{tabular}{cc|cc}
\hline $\begin{array}{c}\text { BChE } \\
\text { phenotype }\end{array}$ & Frequency /\% & $\begin{array}{c}\text { PON } \\
\text { phenotype }\end{array}$ & Frequency / \% \\
\hline UU & 93 & Low activity & $\approx 55$ \\
UA & 4.8 & Medium and & \\
UF & 1.5 & high activity & $\approx 45$ \\
AA & 0.32 & & \\
Other & 0.38 & & \\
\hline
\end{tabular}

Table 3 Butyrylcholinesterase (BChE) and paraoxonase (PON) activities in human serum of diseased individuals relative to healthy (32-35)

\begin{tabular}{lcc}
\hline Disease & BChE & PON \\
\hline Hyperlipaemia and Hyperlipaemia+NIDDM & Slightly increased & Decreased \\
Type II DM & - & Slightly increased \\
HELP-treated hyperlipaemia & - & Decreased \\
Uremia+hemodialysis & - & Decreased \\
Dementia & Decreased & Slightly decreased \\
\hline
\end{tabular}

NIDDM: non-insulin-dependent diabetes mellitus, HELP: heparin-induced extracorporal lipid precipitation 
$\mathrm{BChE}$ phenotyping and activity measurements (26, 27). Only some clinical laboratories are screening their patients and issuing warning cards for carriers of the suxamethonium-sensitive BChE variants (25).

The distribution of human PON phenotypes is also shown in Table 2 (28-30), and the results were obtained from about 500 healthy male and female adults, but not from the same population, as in the $\mathrm{BChE}$ activity study. Activities were measured with paraoxon (O,O-diethyl-4-nitrophenyl phosphate) as substrate. Only the low PON activity mode was well separated, while the heterozygous medium mode and the high activity mode overlapped. Each serum contained both the EDTA-sensitive and EDTAinsensitive PON. With paraoxon as substrate, up to $10 \%$ of the total activity was EDTA-insensitive, while with phenylacetate as substrate only $1 \%$ to $2 \%$ was EDTA-insensitive. The EDTA-insensitive activities were distributed unimodally, but asymmetrically.

The distribution profiles of $\mathrm{BChE}$ and PON in healthy individuals from Croatia are similar to the profiles known for other Caucasian populations (31).

Certain diseases are reflected in $\mathrm{BChE}$ and $\mathrm{PON}$ activities, but not sufficiently pronounced to use these enzymes as possible biomarkers for a given disease. Table 3 summarizes the studies on the profiles of $\mathrm{BChE}$ and $\mathrm{PON}$ in these patients conducted in Croatia so far (32-35).

\section{ORGANOPHOSPHATES AND METABOLITES IN HUMAN BLOOD AND URINE}

The detection of an OP compound in blood, other tissues or urine is the only direct proof of $\mathrm{OP}$ absorption or poisoning. As OPs are not stable in humans, parent compounds are seldom detected, and methods are therefore developed for the analysis of both metabolites and parent compounds.

Nineteen OP compounds are approved as pesticides in Croatia (36). Most contain $\mathrm{P}=\mathrm{S}$ bonds in the molecule. These convert into the corresponding oxon derivatives $(\mathrm{P}=\mathrm{O})$ in vivo, thus becoming cholinesterase inhibitors.

Procedures used to analyse OP pesticides and their metabolites are gas chromatography and mass spectrometry. Procedures used or developed in Croatia for the analysis of dimethyl- and diethyl-phosphorus metabolites and parent compounds are summarised in reference (37).
Over a decade, several studies were conducted on workers spraying OP pesticides and on accidentally or intentionally poisoned individuals, comprising about 130 subjects (38-43). The OP compounds involved were methidathion, amidothion, azinphos-methyl, quinalphos, chlorpyrifos, phosalone, thiomethon and malathion. Blood cholinesterase activities in the workers were also measured.

The parent compound was detected in the serum or urine of but a few subjects, while almost all urine samples, and many serum samples, contained one or more OP metabolites. The excretion of metabolites via urine was biphasic with a rapid initial rate. No correlation was observed between blood cholinesterase inhibition and metabolite concentrations in urine. However, urine metabolites were detected earlier than cholinesterase inhibition in blood. It therefore seems that urine metabolites are more sensitive markers of OP absorption than cholinesterase inhibition in blood.

\section{METHODS FOR DETECTING ORGANOPHOSPHATES BY MEANS OF CHOLINESTERASE INHIBITION}

Absorption of an OP compound is usually detected by measuring cholinesterase activity in human blood which contains both AChE and BChE. The target enzyme of OP toxicity is AChE. However, many OPs inhibit BChE faster than $\mathrm{AChE}$, and $\mathrm{BChE}$ is therefore a more sensitive indicator of absorption. Consequently, both $\mathrm{AChE}$ and $\mathrm{BChE}$ activities should be measured in order to obtain more information about OP absorption. However, caution is advised when low cholinesterase activities in human blood are taken as proof of OP absorption, because cholinesterases are also inhibited by other compounds such as carbamates. Furthermore, BChE activities are affected by a wide range of physiological and pathological conditions, while $\mathrm{AChE}$ activities remain largely unaffected.

Many laboratory and field methods have been developed for measuring cholinesterase activities in human blood (cf. 44). In order to determine erythrocyte $\mathrm{AChE}$ and plasma $\mathrm{BChE}$ in whole blood, one must either separate these enzymes or apply selective substrates and/or inhibitors to assay only one enzyme in the presence of the other. Each of these approaches is subject to some intrinsic error, 
as no known substrate or inhibitor is fully selective for either $\mathrm{AChE}$ or $\mathrm{BChE}$, and it is difficult to achieve full separation of erythrocytes from plasma without the loss of some activity.

At present, the most widely used is the spectrophotometric method of Ellman et al. (45) for measuring the hydrolysis of thiocholine ester substrates (acetylthiocholine, butyrylthiocholine, propionylthiocholine) with the chromogenic thiol reagent DTNB. Over the years this method underwent reassessments and modifications, and protocols have been developed for laboratory and field application. Absorption spectra of the reduced Ellman reagent have been studied with respect to the effect of temperature on the absorbance maxima. Molar absorption coefficients have been reassessed and wavelengths for the assay suggested with respect to the interference of haemoglobin absorption on the assay (46). Cholinesterase activities are usually expressed per volume of blood or plasma or packed erythrocytes. The alternative suggestion has been evaluated to express AChE activities per haemoglobin contents. Many selective inhibitors have been tested for the separate analysis of $\mathrm{AChE}$ and $\mathrm{BChE}$ in whole blood. The reversible inhibitor ethopropazine, a phenothiazine derivative, seems a convenient compound (cf. 47). Under given experimental conditions and in the presence of 1.0 mmol L ${ }^{-1}$ acetylthiocholine, ethopropazine $(20 \mu \mathrm{mol}$ $\mathrm{L}^{-1}$ ) inhibits only $5 \%$ to $10 \%$ of the erythrocyte AChE, while the BChE U-variant is inhibited $98 \%$ and the A-variant $74 \%$. Using ethopropazine as a selective inhibitor, an improved determination of $\mathrm{AChE}$ activities in whole blood was suggested, that is suitable for measuring low AChE activities in the whole blood of an OP-poisoned individual (48). A method suitable for routine assays, even under field conditions, based on the use of ethopropazine as a selective inhibitor and acetylthiocholine as a suitable substrate, has been suggested, validated, and compared with other simple and routine protocols (49).

Cholinesterase inhibition is not only used to detect human absorption of OPs, but also to detect OP compounds in media other than whole blood.

Some field kits for detecting OP compounds in the air have a BChE preparation in one compartment of the indicator tube and a $\mathrm{BChE}$ substrate and a pH-indicator in the other compartment (50). When air is sucked through the indicator tube, the two compartments get mixed, and the change in the intensity of the indicator colour points to the presence of a cholinesterase inhibitor. Based on the same principle, a field kit was developed to detect OP compounds in drinking water (51). In this kit, the reagent is DTNB and the BChE substrate is a thiocholine ester. Both field kits have been developed, tested and applied with emphasis on the detection of $\mathrm{OP}$ warfare agents, i.e. experimental conditions were standardized against known concentrations of the OP agents. Neither kit is specific for OPs, but detects other cholinesterase inhibitors as well.

Malathion is a widely used pesticide. Waterdispersible malathion powders sometimes contain toxic impurities, iso-malathion in particular. Preparations of malathion should therefore be tested for the presence of cholinesterase inhibitors. These can be detected with an enzyme test based on the inhibition of eel AChE, measured with acetylthiocholine as substrate and DTNB as the thiol reagent (52). The test has a detection limit of $0.01 \%(\mathrm{w} / \mathrm{w})$ and a high correlation with thin-layer chromatography detection of isomalathion.

Due to the worldwide use of OP pesticides and the potential use of OP warfare agents, there is a need to standardise a simple and reliable method for cholinesterase activity measurement on an international basis, in order to better compare data obtained by different laboratories and exchange samples for the confirmation of results.

\section{REFERENCES}

1. Reiner E, Radić Z, Simeon-Rudolf V. Introductory overview on mechanisms of organophosphate toxicity and detoxication with emphasis on studies in Croatia. Toxicol Lett - Abstracts of The EUROTOX 2006/6 CTDC Congress 2006;164S:S8-9.

2. Stojiljković MP, Jokanović M. Pyridinium oximes: rationale for their selection as causal antidotes against organophosphate poisonings and current solutions for auto-injectors. Arh Hig Rada Toksikol 2006;57:43543.

3. Dawson RM. Review of oximes available for the treatment of nerve agent poisoning. J Appl Toxicol 1994;14:17-31.

4. Bajgar J. Organophosphates/nerve agent poisoning: mechanism of action, diagnosis, propylaxis, and treatment. Adv Clin Chem 2004;38:151-216.

5. Gupta RC, editor. Toxicology of Organophosphate and Carbamate Pesticides. Burlington: Elsevier Academic Press; 2006.

6. Szinicz L, Reiner E, Eyer P, guest editors, Worek F, co-editor. New Strategies in Medical Protection 
against Organophosphorus Compounds. Toxicology 2007;233(special issue 1-3):1-240.

7. Primožič I, Odžak R, Tomić S, Simeon-Rudolf V, Reiner E. Pyridinium, imidazolium, and quinuclidinium oximes: Synthesis, interaction with native and phosphorylated cholinesteerases, and antidotes against organophosphorus compounds. J Med Chem Def 2004-2005;2:1-30. ŠDisplayed 2 June 2004Ć Available at http://www.jmedcbr.org.

8. Reiner E, Simeon-Rudolf V. Pyridinium, imidazolium and quinuclidinium compounds: toxicity and antidotal effects against the nerve agents tabun and soman. Arh Hig Rada Toksikol 2006;57:171-9.

9. Lucić Vrdoljak A, Čalić M, Radić B, Berend S, Jun D, Kuča K, Kovarik Z. Pretreatment with pyridinium oximes improves antidotal therapy against tabun poisoning. Toxicology 2006;228:41-50.

10. Odžak M, Čalić M, Hrenar T, Primožič I, Kovarik Z. Evaluation of monoquaternary pyridinium oximes potency to reactive tabun-inhibited human acetylcholinesterase. Toxicology 2007;233:85-96.

11. Odžak R, Oršulić $M$, Tomić $S$. Synthesis of glucoconjugates with heterocyclic oximes. Toxicology 2007;233:227-8.

12. Škare D, Radić B, Lucić A, Peraica M, Domijan A-M, Milković-Kraus S, Bradamante V, Jukić I. Adamantyl tenocyclidines: Adjuvant therapy in poisoning with organophosphorus compounds and carbamates. Arch Toxicol 2002;76:173-7.

13. Lucić Vrdoljak A, Radić B, Garaj-Vrhovac V, Kopjar N, Žlender V. Evaluation of antidotal effects of adamantyl derivative Tamorf in soman poisoning. J Appl Toxicol 2006;26:56-63.

14. Radić B, Lucić Vrdoljak A, Petek MJ, Kopjar N, Želježić D. In vitro biological efficiency of tenocyclidine TCP and its adamantane derivative TAMORF. Toxicol in Vitro 2006;20:1455-64.

15. Radić Z, Reiner E, Simeon V. Binding sites on acetylcholinesterase for reversible ligands and phosphorylating agents: A theoretical mode1 tested on haloxon and phosphostigmine. Biochem Pharmacol 1984;33:671-7.

16. Reiner E. Inhibition of acetylcholinesterase by 4,4'bipyridine and its effect upon phosphylation of the enzyme. Croat Chem Acta 1986;59:925-31.

17. Radić Z, Reiner E, Taylor P. Role of the peripheral anionic site on acetylcholinesterase: Inhibition by substrates and coumarin derivatives. Molec Pharmacol 1991;39:98-104.

18. Simeon-Rudolf V, Reiner E, Škrinjarić-Špoljar M, Radić B, Lucić A, Primožić I, Tomić S. Quinuclidiniumimidazolium compounds: Synthesis, mode of interaction with acetylcholinesterase and effect upon Soman intoxicated mice. Arch Toxicol 1998;72:28995.
19. Simeon-Rudolf V, Kovarik Z, Radić Z, Reiner E. Reversible inhibition of acetylcholinesterase and butyrylcholinesterase by 4,4'-bipyridine and by a coumarin derivative. Chem-Biol Interactions 1999;119/120:119-28.

20. Reiner E, Simeon-Rudolf V. Cholinesterases: substrate inhibition and substrate activation. Pflugers Archiv - Eur J Physiol 2000;440(Suppl):R118-20.

21. Reiner E, Radić Z. Mechanism of action of cholinesterase inhibitors. In: Giacobini E, editor. Cholinesterases and Cholinesterase Inhibitors. London: Martin Dunitz Ltd.; 2000. p. 103-19.

22. Simeon $V$, Radić $Z$, Reiner E. Inhibition of cholinesterases by the oximes P2AM and Toxogonin. Croat Chem Acta 1981;54:473-80.

23. Čalić M, Lucić Vrdoljak A, Radić B, Jelić D, Jun D, Kuča $\mathrm{K}$, Kovarik Z. In vitro and in vivo evaluation of pyridinium oximes: Mode of interaction with acetylcholinesterase, effect on tabun- and soman-poisoned mice and their cytotoxicity. Toxicology 2006;219:85-96.

24. Kovarik Z, Čalić M, Šinko G, Bosak A. Structure-activity approach in the reactivation of tabun-phosphorylated human acetylcholinesterase with bispyridinium/para/aldoximes. Arch Ind Hyg Toxicol 2007;58:201-9.

25. Šurina B, Nosso D, Šiftar Z, Flegar-Meštrić Z, SimeonRudolf V. Cholinesterase unit establishment and issuing of "Warning cards" for carriers of suxamethonium sensitive serum butyrylcholinesterase variants. Coll Antropol 2004;28(Suppl 2):297-304.

26. Simeon-Rudolf V, Evans RT. Interlaboratory study into the proficiency of attribution of human serum butyrylcholinesterase phenotypes: Reference values of activities and inhibitor numbers. Acta Pharm 2001;51:289-96.

27. Simeon-Rudolf V, Evans RT. Interlaboratory study into the proficiency of serum cholinesterase activity measurement. Arh Hig Rada Toksikol 2001;52:299305.

28. Reiner E, Radić Z, Simeon V. Hydrolysis of paraoxon and phenylacetate by human serum esterases. In: Reiner E, Aldridge WN, Hoskin FCG, editors. Enzymes Hydrolysing Organophosphorus Compounds; Chichester: Ellis Horwood Ltd.; 1989. p. 30-40.

29. Reiner E, Simeon-Rudolf V, Škrinjarić-Špoljar $M$. Catalytic properties and distribution profiles of paraoxonase and cholinesterase phenotypes in human sera. Toxicol Lett 1995;82/83:447-52.

30. Juretić D, Tadijanović M, Rekić B, Petlevski R, SimeonRudolf V. Paraoxonase phenotype distribution in a healthy population group from the Slavonski Brod area. Biochem Med 2004;14:51-6.

31. Geldmacher V, Mallincrodt M, Diepgen TL. The human serum paraoxonase - Polymorphism and specificity. Toxicol Environ Chem 1988;18:79-196.

32. Pavković E, Simeon V, Reiner E, Sučić M, Lipovac V. 
Serum paraoxonase and cholinesterase activities in individuals with lipid and glucose metabolism disorders Chem Biol Interact 1993;87:179-82.

33. Reiner E, Pavković E, Simeon-Rudolf V, Sučić $M$, Lipovac V. Activities of serum esterases in patients with hyperlipidaemia. Croat Chem Acta 1996;69:317-25.

34. Juretić D, Tadijanović M, Rekić B, Simeon-Rudolf V, Reiner E, Baričić M. Serum paraoxonase activities in hemodialyzed uremic patients: Cohort study. Croat Med J 2001;42:146-50.

35. Juretić D, Motejlkova A, Kunović B, Rekić B, FlegarMeštrić Z, Vujić L, Mesić R, Lukač-Bajalo J, SimeonRudolf $\mathrm{V}$. Paraoxonase/arylesterase in serum of patients with type II diabetes mellitus. Acta Pharm 2006;56:5968.

36. Lista otrova koji se mogu stavljati u promet [List of toxic compounds approved for the market, in Croatian]. Narodne Novine 30/2005.

37. Vasilić Ž, Drevenkar V, Fröbe Z, Štengl B, Tkalčević B. The metabolites of organophosphorus pesticides in urine as an indicator of occupational exposure. In: Merian E, Frei RW, Lawrence JF, Brinkman UA Th, editors. Chemistry and Fate of Organophosphorus Compounds. Montreux: Gordon and Breach Science Publishers S.A.; 1987. p. 57-73.

38. Vasilić Ž, Štengl B, Drevenkar V. Dimethylphosphorus metabolites in serum and urine of persons poisoned by malathion or thiometon. Chem Biol Interact 1991;119120:479-87.

39. Drevenkar V, Radić Z, Vasilić Ž, Reiner E. Dialkylphosphorus metabolites in the urine and activities of esterases in the serum as biochemical indices for human absorption of organophosphorus pesticides. Arch Environ Contam Toxicol 1991;20:41722.

40. Vasilić Ž, Drevenkar V, Rumenjak V, Štengl B, Fröbe Z. Urinary excretion of diethylphosphorus metabolites in persons poisoned by quinalphos or chlorpyrifos. Arch Environ Contam Toxicol 1992;22:351-7.

41. Vasilić Ž, Drevenkar V, Štengl B, Fröbe Z, Rumenjak V. Diethylphosphorus metabolites in serum and urine of persons poisoned by phosalone. Chem Biol Interact 1993;87:305-13.

42. Drevenkar V, Vasilić Ž, Štengl B, Fröbe Z, Rumenjak V. Chlorpyrifos metabolites in serum and urine of poisoned persons. Chem Biol Interact 1993;87:31522.

43. Drevenkar V, Štengl B, Fröbe Z. Microanalysis of dialkylphosphorus metabolites of organophosphorus pesticides in human blood by capillary gas chromatography and by phosphorus-selective and ion trap detection. Anal Chim Acta 1994;290:277-86.

44. Reiner E. Simeon-Rudolf V. Methods for measuring cholinesterase activities in human blood. In: Gupta RC, editor. Toxicology of Organophosphate and Carbamate Compounds. Burlington: Elsevier Academic Press, 2006. p. 199-208.

45. Ellman GL, Courtney KD, Andres V, Featherstone RM. A new and rapid colorimetric determination of acetylcholinesterase activity. Biochem Pharmacol 1961;7:88-95.

46. Eyer P, Worek F, Kiderlen D, Šinko G, Štuglin A, SimeonRudolf $\mathrm{V}$, Reiner E. Molar absorption coefficients for the reduced Ellman reagent: Reassessment. Anal Biochem 2003;312:224-7.

47. Simeon-Rudolf V, Šinko G, Štuglin A, Reiner E. Inhibition of human blood acetylcholinesterase and butyrylcholinesterase by ethopropazine. Croat Chem Acta 2001;74:173-82.

48. Worek F, Mast U, Kiderlen D, Diepold Ch, Eyer P. Improved determination of acetylcholinesterase activity in human whole blood. Clin Chim Acta 1999;288:7390.

49. Reiner E, Šinko G, Škrinjarić-Špoljar M, Simeon-Rudolf $\mathrm{V}$. Comparison of protocols for measuring activities of human blood cholinesterases by the Ellman method. Arhiv Hig Rada Toksikol 2000;51:13-8.

50. Simeon-Rudolf V, Škrinjarić-Špoljar M, Reiner E, Orehovec Z, Jukić I, Bokan S, Smoljan B. Identification of the contents and shelf-life of indicator tubes from field kits for detection of organophosphorus compounds in the air. Arhiv Hig Rada Toksikol 1997;48:219-24.

51. Reiner E, Simeon V, Šimaga Š, Cizl S, Jeličić D, Šumanović V, Batinić D. A field-test for detecting organophosphorus compounds in water. Arhiv Hig Rada Toksikol 1993;44:159-62.

52. Reiner E, Radić Z. An enzyme test for determining isomalathion impurities in water-dispersable powders of malathion. Bull WHO 1986;64:397-401. 


\section{Sažetak}

\section{MEHANIZAM TOKSIČNOSTI I DETOKSIKACIJE ORGANOFOSFORNIH SPOJEVA S NAGLASKOM NA} ISTRAŽIVANJA U HRVATSKOJ

Prikazana su istraživanja vođena u Hrvatskoj na različitim područjima mehanizma toksičnosti i detoksikacije organofosfornih (OP) spojeva. Jedno je područje sinteza antidota protiv otrovanja OP spojevima i testiranje in vivo antidota na eksperimentalnim životinjama. Istraživanja in vitro odnose se na mehanizam reverzibilne inhibicije acetilkolinesteraze (AChE) i buturilkolinesteraze (BChE), zaštitu kolinesteraza od inhibicije OP spojevima te reaktivaciju fosfiliranih kolinesteraza. Treće je područje distribucija fenotipova $\mathrm{BChE} \mathrm{i}$ paraoksonaze (PON) u odabranim populacijama te detekcija OP spojeva i njihovih metabolita u ljudima. Na kraju su opisane metode detekcije OP spojeva u ljudskoj krvi i drugim medijima koje se osnivaju na inhibiciji kolinesteraza.

KLJUČNE RIJEČI: acetilkolinesteraza, antidoti za organofosfate, butirilkolinesteraza, detekcija organofosfata, interakcija organofosfata s esterazama, paraoksonaza

\section{CORRESPONDING AUTHOR:}

Elsa Reiner, Ph.D.

Institute for Medical Research and Occupational Health PO Box 291, HR-10001 Zagreb, Croatia

E-mail: ereiner@imi.hr 